\title{
TINJAUAN YURIDIS KARTEL TIKET PESAWAT MASKAPAI DOMESTIK PENERBANGAN PT. GARUDA INDONESIA DENGAN LION GROUP
}

\author{
Oleh: \\ Eka Putri Fauzia Ikromi*, Sri Maharani M.T.V.M.** \\ *Mahasiswa Fakultas Hukum Universitas Pembangunan Nasional "Veteran" Jawa Timur \\ ** Dosen Fakultas Hukum Universitas Pembangunan Nasional "Veteran" Jawa Timur \\ Email: ekaputrifi24@gmail.com/runnei2014@gmail.com
}

\section{ABSTRACT}

In order to create conducive stability and business competition in Indonesia, Law Number 5 Year 1999 concerning the prohibition of monopolistic practices and unfair business competition is the main condition to be considered in Indonesia. In its enforcement, the Government established the KPPU institution as a supervisor of the actions of business actors which are often violated to increase profits for personal interests, one of which is price conspiracy or so-called cartels. The majority who do this come from business people who control the Indonesian market economy. The aviation business sector in Indonesia is currently receiving the spotlight from KPPU for an indication of a flight ticket cartel which is the two major domestic airlines in Indonesia, namely PT. Garuda Indonesia and Lion Group. Even if there is no written agreement, the cartel can be charged to business actors who in practice carry out prohibited acts and can harm other airlines. The actions of the airline PT. Garuda Indonesia and Lion Group are reviewed legally based on existing business competition regulations in Indonesia and are examined according to the procedures set out in Perkom Number 1 of 2019. This review aims to assess the alleged flight ticket cartel by both domestic airlines, whether it has violated it or not.

Keyword: KPPU, Cartel and Law Number 5 Year 1999

\begin{abstract}
ABSTRAK
Untuk menciptakan stabilitas yang kondusif dan persaingan bisnis di Indonesia, UndangUndang Nomor 5 Tahun 1999 tentang larangan praktik monopoli dan persaingan usaha tidak sehat adalah syarat utama yang harus dipertimbangkan di Indonesia. Dalam penegakannya, Pemerintah membentuk lembaga KPPU sebagai pengawas tindakan pelaku usaha yang kerap dilanggar untuk menambah keuntungan demi kepentingan pribadi, salah satunya adalah konspirasi harga atau yang disebut kartel. Mayoritas yang melakukan ini berasal dari pelaku bisnis yang mengendalikan ekonomi pasar Indonesia. Sektor bisnis penerbangan di Indonesia saat ini menerima sorotan dari KPPU untuk indikasi kartel tiket penerbangan yang merupakan dua maskapai domestik utama di Indonesia, yaitu PT. Garuda Indonesia dan Lion Group. Bahkan jika tidak ada perjanjian tertulis, kartel dapat dibebankan kepada pelaku bisnis yang dalam praktiknya melakukan tindakan yang dilarang dan dapat membahayakan maskapai lain. Tindakan maskapai PT. Garuda Indonesia dan Lion Group ditinjau secara legal berdasarkan peraturan persaingan bisnis yang ada di Indonesia dan diperiksa sesuai dengan prosedur yang ditetapkan dalam Perkom Nomor 1 tahun 2019. Tinjauan ini bertujuan untuk menilai dugaan kartel tiket penerbangan oleh kedua maskapai domestik, apakah memiliki melanggar atau tidak.
\end{abstract}

Kata kunci: KPPU, Kartel, dan Undang-Undang Nomor 5 Tahun 1999 


\section{PENDAHULUAN}

Indonesia merupakan salah satu negara ASEAN yang bergabung dalam ASEAN Free Trade Area (AFTA) yaitu kawasan perdagangan bebas ASEAN. Terbentuknya AFTA berdasarkan kesepakatan negara-negara ASEAN yang bergabung saat Konferensi Tingkat Tinggi (KTT) ASEAN keempat di Singapura Tahun 1992. Tujuan negara-negara ASEAN yang bergabung guna meningkatkan investor asing dalam meningkatkan perdagangan antar negara-negara ASEAN. Selain itu, daya saing antar negara-negara ASEAN perlu ditingkatkan dengan menjadikan ASEAN sebagai basis produksi pasar dunia.

AFTA membuka peluang besar terhadap pelaku usaha dalam menjalankan usaha di dalam negeri maupun antar negara kawasan ASEAN. Bahkan saat ini, pembebasan bea untuk barang impor di kawasan ASEAN pun telah diterapkan setelah negara-negara ASEAN membentuk suatu komunitas yaitu Masyarakat Ekonomi ASEAN (MEA) tahun 2015. Tergabungnya Indonesia pada AFTA tidak menutup kemungkinan terjadi krisis moneter pada Tahun 1998. Hal ini membuat Indonesia meminta bantuan kepada International Monetary Fund (IMF) berupa pinjaman dana. IMF akan memberikan pinjaman dengan perjanjian salah satunya menyatakan syarat bahwa Indonesia harus melikuidasi bank-bank yang bermasalah, menjual BUMN dan membentuk Badan Penyehatan Perbankan Nasional (BPPN).

Pemulihan perekonomian Indonesia ditandai dengan pembentukan UndangUndang Nomor 5 Tahun 1999 tentang Larangan Praktek Monopoli dan Persaingan Usaha Tidak Sehat. Penegakan atas peraturan ini Pemerintah membentuk suatu Lembaga berupa Komisi Pengawasan Persaingan Usaha (KPPU). Guna mewujudkan stabilitas dan persaingan usaha secara kondusif, maka peraturan larangan praktek monopoli dan persaingan usaha tidak sehat sebagai syarat utama untuk diperhatikan.

Adanya suatu peraturan maupun badan pengawas persaingan usaha, pelaku usaha sampai saat ini masih ada yang melakukan pelanggaran hukum dan itu menimbulkan kerugian bagi pelaku usaha lainnya serta masyarakat. Perbuatan yang kerap kali dilanggar oleh pelaku usaha untuk meningkatkan keuntungan bagi kepentingan pribadi yaitu berupa persekongkolan harga atau disebut dengan kartel. Mayoritas yang melakukan hal ini berasal dari kalangan pelaku usaha yang menguasai ekonomi pasar Indonesia. Berbagai sektor usaha di Indonesia yang terindikasi melakukan perbuatan persaingan usaha tidak sehat diberi peringatan oleh KPPU dan pelaku usaha yang telah terbukti melanggar akan dikenakan sanksi baik administrasi maupun denda.

Sistem ekonomi Indonesia memberikan satu ruang interaksi antara mekanisme pasar dan keterlibatan negara. Negara menghormati mekanisme pasar dan negara juga berhak menintervensi dalam kondisi tertentu demi kesejahteraan masyarakat Indonesia. Peranan negara terhadap mekanisme pasar bisa menggerakan dengan persaingan sempurna ataupun persaingan tidak sempurna. Apabila persaingan tidak sempurna diterapkan pada pasar, maka akan memberikan peluang juga terhadap pelaku usaha untuk memiliki kekuatan pasar (market power) atau disebut juga dengan posisi dominan yang secara jelas disebutkan dalam Pasal 1 angka 4 Undang-Undang Nomor 5 Tahun 1999 tentang Larangan Praktek Monopoli dan Persaingan Usaha Tidak Sehat.

Praktek kartel pada pasar membatasi masuknya pelaku usaha baru yang mampu menawarkan harga lebih 
kooperatif dengan kualitas produknya. Sehubungan dengan praktek kartel di Indonesia, dilakukan oleh pelaku usaha yang perusahaannya sudah besar di pasar sehingga pelaku usaha yang baru tidak terkemuka di publik. Maka dari itu KPPU mengawasi setiap pergerakan pelaku usaha Indonesia. KPPU juga berwenang menyelidiki pelaku usaha yang dalam pengawasannya terindikasi kartel tanpa adanya laporan dari masyarakat terlebih dahulu.

Saat ini, pihak KPPU mulai meneliti dan mengawasi jalannya penetapan harga tiket pesawat yang dilakukan oleh maskapai domestik salah satunya Garuda Indonesia dan Lion Group. KPPU merasakan kecurigaan adanya persekongkolan harga tiket di dua maskapai besar domestik ini. Kenaikan tiket pesawat di dua maskapai domestik ini juga dirasakan masyarakat terlebih perjalanan di Indonesia sendiri jauh lebih mahal dibandingkan perjalanan ke luar negeri dengan maskapai asing.

\section{METODE PENELITIAN}

Penelitian merupakan suatu kegiatan ilmiah yang berkaitan dengan analisis dan kontruksi yang dilakukan dengan metode tertentu, bersifat sistematis dan konsisten untuk mengungkapkan kebenaran.

Jenis penelitian yang digunakan oleh Penulis adalah penelitian normatif atau Yuridis - Normatif. Beberapa alasan penulis menggunakan penelitian yuridis normatif, salah satunya yaitu persoalan yang diteliti penulis sangat complicated, sehingga membutuhkan penafsiran atas setiap peraturan yang terkait. Penelitian normatif disebut juga dengan penelitian hukum doktrinal. Pada penelitian hukum jenis ini kerap kali hukum dikonsepsikan sebagaimana yang tertulis dalam peraturan

1 Amiruddin, Pengantar Metodelogi Hukum, cetakan ke 6, Jakarta : PT Raja Grafindo Persada, 2012, hlm 118. perundang-undagan (law in books) atau hukum dikonsepkan sebagai kaidahkaidah atau norma yang merupakan patokan berperilaku manusia. ${ }^{1}$ Penelitian ini dapat dilakukan terhadap bahan hukum primer dan bahan hukum sekunder. Keduanya termasuk data sekunder, selama bahan-bahan tersebut mengandung kaidah hukum di dalam penelitian ini.

\section{HASIL DAN PEMBAHASAN}

Dugaan KPPU terhadap indikasi kartel tiket pesawat atas maskapai PT. Garuda Indonesia dengan Lion Group berdasarkan hasil penafsiran Pasal 11 Undang-Undang Nomor 5 Tahun 1999 tentang Larangan Praktek Monopoli dan Persaingan Usaha Tidak Sehat, termasuk ke dalam bentuk kartel harga. Kartel harga disepakati oleh para pelaku usaha yang bersepakat atas suatu kolusi, baik kolusi implisit ataupun kolusi eksplisit mengenai harga minimum atau maksimum barang dan/atau jasa yang diperjualbelikan. Selain itu, pelaku usaha yang termasuk dalam jajaran anggota kartel dilarang menjual barang dan/atau jasanya diluar harga yang telah disepakati. Parameter yang mengindikasikan kartel tiket pesawat maskapai domestik PT. Garuda Indonesia dengan Lion Group termasuk ke dalam kartel harga terlihat dari beberapa hal, diantaranya yaitu:

Pertama, PT. Garuda Indonesia dengan Lion Group menaikan harga tiket pesawat secara bersamaan. Hal serupa juga dilakukan pada saat kedua maskapai ini menurunkan harga tiket pesawatnya, setelah adanya tekanan protes dari masyarakat terhadap harga yang dirasa terlalu tinggi. Disinyalir kuat oleh KPPU adanya persekongkolan harga antara PT. Garuda Indonesia dengan Lion Group 
setelah adanya laporan dari masyarakat yang merasa harga tiket pesawat tidak wajar dikarenakan harga bahan bakar pesawat (avtur) tidak mengalami kenaikan.

Kedua, pada saat konferensi pers yang dipimpin oleh Ketua Umum Asosiasi Perusahaan Penerbangan Nasional Indonesia atau INACA (Indonesia National Air Carriers Assosiaction) yaitu I Gusti Ngurah Askhara sekaligus sebagai Direktur Utama Garuda Indonesia menyatakan sejak awal Februari 2019, dua maskapai domestik PT. Garuda Indonesia dan Lion Group telah menurunkan tarif harga untuk penerbangan domestik khususnya rute Jakarta-Denpasar, Jakarta-Yogyakarta, BandungDenpasar, Jakarta-Surabaya. Setelah konferensi pers berlangsung, penurunan harga tiket pesawat diterapkan untuk beberapa rute lainya oleh kedua group maskapai besar tersebut. Konferensi pers juga dihadiri oleh perwakilan manajemen sejumlah maskapai penerbangan domestik di Indonesia. Beberapa perwakilan maskapai sepakat dengan pernyataan Ketua Umum INACA terkait penurunan harga yang telah dilakukan oleh para maskapai penerbangan. Sepakatnya perwakilan maskapai saat konferensi pers disinyalir KPPU sebagai bentuk persekongkolan antar maskapai dalam menentukan harga tiket pesawat.

Ketiga, pangsa pasar penerbangan di Indonesia saat ini dikuasi oleh kedua maskapai domestik PT. Garuda Indonesia dan Lion Group. Namun, kondisi industri pesawat komersil sedang melemah dan tidak stabil, sehingga hal ini dapat mendorong adanya persekongkolan harga tiket pesawat demi kestabilitas maskapai. Ketika kedua group maskapai domestik bersama-sama menggeser harga tiket pesawat menjadi lebih mahal, KPPU telah menduga adanya aksi persekongkolan antar kedua maskapai tersebut.

Keempat, setelah konferensi pers INACA, dua orang selaku investigator KPPU yang sedang mendalami struktur tarif dan interaksi antar maskapai dalam penetapan harga tiket menjelaskan pada media bahwasannya hasil pengamatan sementara dari investigator KPPU, PT. Garuda Indonesia dengan Lion Group memiliki posisi seimbang di pasar. Apabila memiliki posisi yang sama kuatnya, maka salah satu maskapai penerbangan tidak perlu mengikuti penaikan harga tiket pesawat di maskapai lainnya. Namun, pada nyatanya PT. Garuda Indonesia dengan Lion Group menaikan harga tiket pesawat di waktu yang sama.

Kelima, bergabungnya Sriwijaya Air Group (Sriwijaya Air dan NAM Air) pada PT. Garuda Indonesia Group melalui kerjasama operasional (KSO) sejak bulan November 2018. KSO merupakan langkah strategis dalam merealisasikan PT. Garuda Indonesia Group mengambil alih (akuisisi) pengelolaan operasional dari Sriwijaya Air Group. Berdasarkan Pasal 11 Undang-Undang Nomor 40 Tahun 2007 tentang Perseroan Terbatas, pengambil alihan yang dimaksudkan sekaligus mengambil alih saham milik suatu perusahaan, sehingga dapat dikendalikan oleh perusahaan yang mengambil alih. Saat itu, Direktur Utama Garuda Indonesia, I Gusti Ngurah Askhara juga menjadi Komisaris Utama di Sriwijaya Air. Selain itu, Direktur Niaga Garuda Indonesia, Pikri Ilham Kurniansyah dan Direktur Utama Citilink Indonesia (entitas maskapai Garuda Indonesia), Juliandra Nurtjahtjo memiliki kedudukan sebagai komisaris di Sriwijaya Air. Dari rangkap jabatan menimbulkan tarif penerbangan Sriwijaya Air dikendalikan oleh PT. Garuda Indonesia. 
Keenam, maskapai penerbangan Air Asia, selaku maskapai milik asing yang cukup eksis di penerbangan Indonesia tidak memiliki mobilitas yang sama di pangsa pasar penerbangan. Adanya pemboikotan maskapai ini oleh agen perjalanan mengakibatkan PT. Garuda Indonesia dan Lion Group menjadi dua maskapai yang menguasai pangsa pasar. Sehingga tarif batas atas pun diberlakukan di kedua maskapai seperti saat ini. Kompleksitas kenaikan harga tiket pesawat rata-rata 50\% (Lima Puluh Persen) dari harga awal untuk masingmasing maskapai. Sedangkan harga tiket pesawat maskapai Air Asia di rute yang sama tidak ada kenaikan harga.

Ketujuh, meskipun jumlah rute penerbangan Lion Group lebih banyak daripada PT. Garuda Indonesia, keduanya juga memiliki mayoritas rute penerbangan yang sama di Indonesia. Selain itu, layanan yang disediakan dari kedua maskapai besar ini terdapat kelas Full Service Agency (FSA) dan ada Sistem pembuktian yang dilakukan oleh KPPU berbeda dengan sistem yang dilakukan pada acara pidana maupun acara perdata pada umumnya. Hal yang membedakan sistem pembuktian di KPPU dengan hukum acara lainnya yaitu berupa indirect evidence, yang antara lain dilakukan melalui penggunaan berbagai hasil analisis ekonomi yang bisa membuktikan adanya korelasi antar satu fakta ekonomi dengan fakta ekonomi lainnya. sistem ini menemukan alat bukti secara tidak langsung. Sistem pembuktian kartel yang dilakukan KPPU menggunakan pendekatan Rule of Reoson. Artinya, dalam membuktikan kebenaran atas terjadinya suatu kartel, perlu dilakukan pemeriksaan sacara mendalam mengenai alasan para pelaku usahaGaruda Indonesia, Citilink dan Batik Air, dan untuk kelas LCC ada pada maskapai Lion Air, Wings Air, Nam Air dan Sriwijaya Air.
Berdasarkan ketujuh hal yang telah terlihat oleh KPPU, dugaan kartel tiket pesawat yang dilakukan para pihak maskapai penerbangan menguatkan laporan dugaan kartel dominan berbentuk kartel harga. Meski demikian, korelasi dengan bentuk kartel lainnya pun tetap ada dalam peristiwa kartel tiket pesawat kedua maskapai besar di Indonesia ini. Beberapa korelasi antar bentuk kartel dengan kartel harga tiket pesawat ini yaitu:

Pertama, korelasi kartel harga dengan kartel syarat pada tiket pesawat maskapai PT. Garuda Indonesia dengan Lion Group. Indikator kartel permasalahan ini tidak terlepas dengan beberapa persyaratan mengenai ketentuan fasilitas yang diberikan kepada konsumen. Syarat yang dibedakan sesuai tarif yang telah ditetapkan bersama serta sesuai kelas penerbangannya, baik kelas berbentuk Full Service Agency (FSA) ataupun kelas berbentuk Lost Cost Carrier (LCC). Saat menggunakan jasa penerbangan kelas atas atau Full Service Agency (FSA) konsumen akan mendapatkan sejumlah layanan diantaranya konsumsi selama perjalanan; tidak adanya delayed (didahulukan) kecuali ada suatu alasan mendesak; bahkan hingga layanan di dalam waiting room. Lain halnya dengan penerbangan menggunakan kelas bawah atau Low Cost Carrier (LCC), konsumen akan ditawarkan konsumsi berbayar (exclude tiket pesawat); kerap kali adanya delayed; dan sebagainya. Syarat akan hal ini tidak menutup akses penuangan pada kolusi yang terpisah dengan kolusi kartel harga ataupun melekat jadi satu di dalamnya.

Kedua, korelasi kartel harga dengan kartel rayon pada tiket pesawat maskapai PT. Garuda Indonesia dengan Lion Group. Hal yang sangat terlihat dari permasalahan ini berupa penguasaan pangsa pasar penerbangan 
dengan rute penerbangan yang sama dan harga yang sama (sesuai bentuk kelas penerbangannya baik Full Service Agency ataupun kelas Low Cost Carrier). Untuk rute penerbangan domestik yang dibuka, dibedakan dalam dua kelas ini berdasarkan jenis pesawat yang tergabung sesuai kelasnya. Semisal rute penerbangan ke daerah Kupang hanya dibutuhkan jenis pesawat kecil atau biasa disebut pesawat ulang-aling. Hal ini disepakatilah jenis pesawat yang dapat terbang ke daerah Kupang pada maskapai PT. Garuda Indonesia berupa NAM Air dan pada maskapai Lion Group berupa Wings Air.

Ketiga, korelasi kartel harga dengan kartel produksi pada tiket pesawat maskapai PT. Garuda Indonesia dengan Lion Group. Kesepakatan produksi yang terjalin berupa penjualan tiket pesawat yang setara kelasnya antar kedua maskapai besar ini di sejumlah agen perjalanan dengan harga yang sama. Kegiatan saling mengintip harga jual dibenarkan oleh Alvin Lie selaku pengamat penerbangan. Sehingga, kedua maskapai ini mencantumkan harga tiket pesawat di pangsa pasar penerbangan baik melalui agen perjalanan maupun counter tiket maskapai pada tarif batas atas. Aksi menggeser harga tiket barawal dari jenis pesawat kategori kelas atas (Full Service Agency) dan beberapa hari setelahnya diikuti oleh jenis pesawat kelas bawah (Low Cost Carrier).

Keempat, korelasi kartel harga dengan kartel pool atau pembagian keuntungan pada tiket pesawat maskapai PT. Garuda Indonesia dengan Lion Group. Guna merealisasikan keuntungan yang didapat berpuluh kali lipat oleh maskapai PT. Garuda Indonesia dan juga Lion Group, maka kedua maskapai besar ini melalui syarat ketentuan yang disepakati, membagi keuntungan atas pendapatan penjualan tiket pesawat dari kelas atas dan juga kelas bawah. Ditambah lagi saat ini, penerapan tarif bagasi diluar harga tiket pesawat menjadikan keuntungan meningkat dari kedua maskapai. Selain itu, suatu fakta dimana pangsa pasar penerbangan yang hanya dikuasai dua maskapai besar ini menjadikan penerapan tarif batas atas di kelas atas dan kelas baawah cukup mudah. Kolusi yang dipergunakan mengenai pembagian keuntungan dapat melekat bersama kolusi kartel harga ataupun terpisah.

Korelasi antar bentuk kartel dari persoalan ini mendominasi bentuk kartel harga lah yang diperuntukan oleh maskapai PT. Garuda Indonesia dengan Lion Group atas tiket pesawat. Adapun ketentuan lain yang relevan mengenai kartel dapat ditemukan dalam beberapa pasal lain yang ada dalam UndangUndang Nomor 5 Tahun 1999, diantaranya yaitu:

Pertama, Pasal 5 mengenai penetapan harga. Secara sekilas pasal ini memiliki kesamaan dengan pasal 11 yang mengatur mengenai kartel, hanya saja perbedaannya terletak pada Pasal 5, dimana pelaku usaha sepakat untuk menetapkan harga. Sedangkan pada kartel yang disepakati oleh anggota adalah mempengaruhi harga dengan jalan mengatur produksi dan atau pemasaran barang atau jasa.

Kedua, Pasal 9 mengenai pembagian wilayah. Pelaku usaha dilarang membuat perjanjian dengan pelaku usaha pesaingnya yang bertujuan untuk membagi wilayah pemasaran atau alokasi pasar terhadap barang dan atau jasa. Rumusan Pasal 9 ini memiliki persamaan dengan Pasal 11. Namun tujuan perjsnjian ini hanya membagi wilayah pemasaran saja tanpa mensyaratkan adanya kesepakatan produksi barang dan atau jasa.

Ketiga, Pasal 10 mengenai Pemboikotan. Persamaan dari pasal ini dengan Pasal 11 dapat mempengaruhi jumlah barang yang beredar di pasar. 
Selain itu kedua pasal ini juga dapat mengakibatkan kerugian bagi konsumen, karena baik melalui kartel maupun pemboikotan selain akan mengakibatkan naiknya harga. Perbedaannya hanya ada pada sarana yang digunakan. Pada kartel pelaku usaha sepakat untuk mengatur produksi, sedangkan dalam pemboikotan pelaku usaha sepakat untuk menghambat pelaku usaha lain yang pada akhirnya akan mengakibatkan terhambatnya produksi barang atau jasa.

Penjatuhan sanksi oleh KPPU bagi pelaku usaha yang melanggar telah diatur pada Bab VIII Undang-Undang Nomor 5 Tahun 1999 dan diperjelas dengan Perkom No.1/2019 tentang Tata Cara Penanganan Perkara Praktek Monopoli dan Persaingan Usaha Tidak Sehat. Sanksi yang dapat dijatuhkan hanya ada 2 (dua) macam, yaitu berupa sanksi administratif dan sanksi pidana yang terdiri dari pidana pokok dan pidana tambahan. Tindakan administratif yang dimaksudkan untuk sanksi dari lembaga KPPU dapat berupa penetapan pembatalan perjanjian yang dilarang; perintah untuk menghentikan integrasi vertikal; perintah untuk menghentikan penyalahgunaan posisi dominan; penetapan pembatalan atas penggabungan atau peleburan badan usaha dan pengambilalihan saham; penetapan pembayaran ganti rugi dan pengenaan denda minimal Rp.1.000.000.000,- (satu milyar rupiah) dan setinggi-tingginya Rp.25.000.000.000,- (dua puluh lima milyar rupiah). Karena dugaan pelanggaran ini berawal dari adanya laporan dari masyarakat atau pelapor, apabila menimbulkan kerugian terhadapnya dan pelapor bisa membuktikan, maka kedua maskapai ini (terlapor) harus membayar biaya ganti rugi kepada pelapor.

Pasal 48 Undang-Undang Nomor 5 Tahun 1999 telah mengatur bahwasannya sanksi pidana pokok yang dimaksudkan dalam persaingan usaha tidak sehat yaitu berupa denda. Pidana pokok denda untuk kartel sesuai ketentuan Pasal 48 ayat (1) UndangUndang Nomor 5 Tahun 1999 yaitu denda minimal Rp.25.000.000.000,(dua puluh lima milyar rupiah) dan maksimal Rp.100.000.000.000,(seratus milyar rupiah). Pidana denda dapat digantikan dengan pidana kurungan selama-lamanya 6 (enam) bulan.

Sanksi pidana tambahan terhadap pelaku usaha yang melanggar dapat berupa pencabutan izin usaha; larangan kepada pelaku usaha yang telah terbukti melakukan pelanggaran terhadap Undang-Undang Nomor 5 Tahun 1999 untuk menduduki jabatan direksi atau komisaris sekurang-kurangnya 2 (dua) tahun; atau penghentian kegiatan atau tindakan tertentu yang menyebabkan timbulnya kerugian pada pihak lain.

Penjatuhan sanksi pidana ini, KPPU tidak berwenang untuk menjatuhkan sanksi ini melainkan Pengadilan Negeri setempat. Telah dijelaskan pada penjelasan umum Undang-Undang Nomor 5 Tahun 1999 mengenai kewenangan KPPU dalam menjatuhkan sanksi hanya sebatas sanksi administratif saja.

\section{KESIMPULAN}

Berdasarkan penelitian mengenai tinjauan yuridis kartel tiket pesawat maskapai penerbangan domestik PT. Garuda Indonesia dengan Lion Group yang telah penulis amati dapat disimpulkan bahwa kedua maskapai penerbangan domestik (PT. Garuda Indonesia dengan Lion Group) memenuhi karakteristik bentuk kartel harga sesuai penjabaran dari Pasal 11 Undang-Undang Nomor 5 Tahun 1999 tentang Larangan Praktek Monopoli dan Persaingan Usaha Tidak Sehat. KPPU juga menemukan fakta bahwasannya maskapai penerbangan domestik PT. Garuda Indonesia dan 
Lion Group memiliki kedudukan yang sama besarnya di pangsa pasar bidang penerbangan Indonesia. Pemasaran tiket pesawat kedua maskapai ini tidak hanya dijual secara personal melainkan melalui agen perjalanan juga, sedangkan maskapai asing yang ada di Indonesia tidak bisa memasarkan di agen perjalanan, sehingga hanya bisa menjual melalui personal.

Pembuktian yang dilakukan KPPU mencari kebenaran materiil bukan formil. KPPU memiliki aturan sendiri (Pedoman utama Undang-Undang Nomor 5 Tahun 1999 bukan Kitab Undang-Undang Hukum Acara Perdata) untuk membuktikan adanya pelanggaran oleh pelaku usaha di Indonesia. Penjatuhan sanksi bagi pelaku usaha yang telah terbukti melakukan tindakan kartel, maka KPPU hanya berwenang menjatuhkan sanksi administratif secara kumulatif maupun alternatif. Sanksi tersebut berupa pembatalan perjanjian dan/atau denda serendah-rendahnya 1 Milyar dan setinggi-tingginya 25 Milyar.

\section{DAFTAR PUSTAKA}

Amiruddin, Pengantar Metodelogi Hukum, Jakarta; PT. Rajagrafindo Persada, 2015.

Junaidi, Negara dan Pasar dalam Bingkai Kebijakan Persaingan, Jakarta; Komisi Pengawasan Persaingan Usaha, 2011.

Lubis, Andi Fahmi, dkk, Hukum Persaingan Usaha Antara Teks \& Konteks, Jakarta; Komisi Pengawasan Persaingan Usaha, 2009. , Hukum Persaingan Usaha

Buku Teks, Jakarta; Komisi Pengawasan Persaingan Usaha, 2017. 